\title{
ASSESSMENT OF PLANT COMMUNITIES AND IDENTIFICATION OF INDICATOR SPECIES OF AN ECOTONAL FOREST ZONE AT DURAND LINE, DISTRICT KURRAM, PAKISTAN
}

\author{
Hussain, M. $.^{1,2}-$ Khan, S. M. ${ }^{1 *}-$ ABD_Allah, E. F. ${ }^{3 *}-$ Ul HaQ, Z. ${ }^{1}-$ Alshahrani, T. S. ${ }^{3}-$ \\ AlqaraWi, A. A. ${ }^{3}-$ Ur RAHMAN, I. $^{4}-$ IQBal, ${ }^{1}{ }^{1}-$ ABDUllaH $^{1}-$ AhMAD, H. $^{5}$ \\ ${ }^{1}$ Department of Plant Sciences, Quaid-i-Azam University, Islamabad, Pakistan \\ ${ }^{2}$ College of Forestry, Guangxi University, Daxuedonglu 100, Nanning, Guangxi 530004, China \\ ${ }^{3}$ Department of Plant Production, College of Food \& Agricultural Sciences, \\ P. O. Box. 2460, Riyadh 11451, Saudi Arabia \\ ${ }^{4}$ Department of Botany, Hazara University, Mansehra, Pakistan \\ ${ }^{5}$ Islamia College, Peshawar, Pakistan \\ *Corresponding authors \\ e-mail: shuja60@gmail.com,eabdallah@ksu.edu.sa \\ (Received $3^{\text {rd }}$ Jan 2019 ; accepted $21^{\text {st }}$ Mar 2019)
}

\begin{abstract}
There must be unique indicator vegetation at Ecotonal Zone in the border region of Pakistan and Afghanistan. Keeping this hypothesis in mind the forest zone of District Kurram at Durand Line was ecologically surveyed. Stations were established, GPS readings, environmental gradients were recorded and soil samples were collected. Data was statistically analysed using PC-ORD version-5 and CANOCO version-4.5. Indicator Species Analysis (ISA), constancy and fidelity level were used to find indicator species of communities. Preliminary results showed that study area hosts 195 vascular plant species belonging to 145 genera and 60 families. Cluster Analysis classified vegetation into four plant communities; (a) Elaeagnus angustifolia-Rosa chinensis-Seriphidium kurramense (b) Platanus orientalisRosa moschata - Epilobium hirsutum (c) Quercus baloot - Jasminum auriculatum-Foeniculum vulgare (d) Quercus dilatata-Hedera nepalensis-Calamintha umbrosa. Nitrogen, Sodium and Potassium were the strongest Physico-chemical factors $(\mathrm{P} \leq 0.05)$ determining plant communities composition. Interestingly, Vincetoxicum cardiostephanum was reported as narrow endemic species. Distinguished indicator species had significant environmental preferences. Variables like grazing and fodder chopping were the major vegetation drivers. Altitude was one of the most important determinants, influencing directly species distribution; Current study could be potentially used elsewhere for vegetation management and conservation strategies.
\end{abstract}

Keywords: Indicators of Transitional Zone; Kurram Agency at Pak Afghan Border; Edaphic Factors

\section{Introduction}

The "ecotone" term was coined by Clements (1905) for transition zone and considered it as a basic unit of landscape ecology (Hansen et al., 1992; Casalini et al., 2019), having extremely unique vegetation, sensitive ecosystems and sharp communities boundaries (Walker et al., 2003; Gonçalves and Souza, 2014), due to abrupt environmental changes (Arellano et al., 2017). These characteristics enhanced significance to check competing ecological theories (Neilson, 1991) and especially climate change management (Kupfer and Cairns, 1996; Judi et al., 2018). The sensitivity and mechanisms of response are differentially varied among ecosystems and 
communities (Huang et al., 2016). The ecosystem continuations particularly for food security are indispensable, not merely to mountainous highland but for lowlands ecosystem; particularly who are dependent on these mountains resources (Rasul, 2010; Dolezal et al., 2016). Therefore, understanding plant and environmental variables correlations, highlighting leading threats and conservation managements are the fascinating research field for ecologists and environmentalists (Tavili and Jafari, 2009; Khan et al., 2016).

Vegetation structure and composition are persuaded by numerous natural and anthropogenic activities (Shaheen et al., 2012; Lyu et al., 2017). Thus, ecosystem services quantification and evaluating vegetation distribution and mapping are important for conservation (Biondi, 2011). Vegetation classification into possible plant communities is also a mandatory part of ecosystem ecology, natural resource management and habitats degradation and fragmentation studies (Khan et al., 2015). It would visualise heterogeneity insights of particular vegetation's type (Haq et al., 2015b). Plant ecologists often hypothesized vegetation driving mechanism and environmental gradients (Willig et al., 2003; Haq et al., 2015a). In mountainous region topography and elevation had strong effects on species diversity, richness and community structures (Khan et al., 2015; Ullah et al., 2015). Anthopogenic disturbances may trigger species shifting (Johnstone and Chapin, 2003) and/or probably eliminate forest products (Brown and Johnstone, 2012) and alter ecosystem function (D'Amato et al., 2011). Long-term overgrazing could have legacial effects on plant diversity, biomass production and edaphic factors (Sher et al., 2010; Sternberg et al., 2017). The soil micro and macro nutrients level can significantly affect species richness and communities Byrne et al. (2017) examined plant's responses against precipitational change and concluded comparatively high level sensitivity. Chang et al. (2018) and Skagen et al. (2018) emphasized forest sensitivity and responses against precipitation variation in ecotones over a time scale.

The indicator species identification ultimately helps in management and restoration of natural resources (Ahmad and Khan, 2004; Mashwani et al., 2011). Keeping the hypothesis in mind; there must be unique indicator vegetation at Ecotonal Zone. The current study was designed to evaluate the vegetation and communities, indicator species and to determine whether soil characteristics and/or anthropogenic activities influences on community distribution in the ecotonal zone. The aim was designed with three main objectives; to quantify vegetation of the ecotonal region, to classify vegetation in major communities along the geo-climatic and altitudinal environmental gradients and to assess the indicator species under the influence of disturbances for future generation management. Additionally, current study documented suggestions for the mountainous plant biodiversity conservation under the scenario of continuous anthropogenic activities.

\section{Material and methods}

\section{Study area description}

The Kurram Valley is situated in the far West of the Khyber Pukhtunkhwa (KP), Pakistan, projecting like a neck in Afghanistan and touching Pukthia, Nangarhar and Khost provinces on its West. Previously, study are was called as FATA but on 24 May 2018 in 25th Constitutional amendment, has been merged to KP and give it agency status, It lies between $33^{\circ} 20^{\prime}$ to $34^{\circ} 10^{\prime}$ N-latitudes and $69^{\circ} 50^{\prime}$ to $70^{\circ} 50^{\prime}$ E-longitude, 
with a total length of $115 \mathrm{~km}$ and covering $3380 \mathrm{~km}^{2}$ area (Fig. 1). District Orakzai and Khyber are lies on its East, District Hangu is situated at southeast, while District North Waziristan is bordered at south. "Koh-e-Sufaid" the part of Western Himalayas, situated on its North. The highest known peak is Sikaram with an altitude of $4728 \mathrm{~m}$ a.s.1. This mountainous range results high annual average precipitation and hence summers remain pleasant. The valley is relatively dry and mostly represents the dry temperate-type of habitat. Heavy snowfall has been experienced in winter with a freezing temperature (Fig. 6). The study area, floristically the part of Western Irano-Turanian region of the Western Himalayan province. Moreover, it gains distinctive position to act as botanical buffer zone between the dry temperate and moist temperate vegetation zones of the Himalayan and Hindu Kush mountainous ranges, respectively. Thus, due to this unique transitional locality, the valley hosts typical vegetation and position in the region. Vegetation is predominated by oak, blue pine, cheer pine forests and chilgoza pine in the extreme border with Afghanistan. Despite of high phytogeographic status factor like; geopolitical conflicts, harsh terrain, long history of Afghan war, low literacy rate and feudal tribal laws divert the concentration of the scientific societies to evaluate the region ecologically. Therefore, project was lunched to evaluate quantitatively.

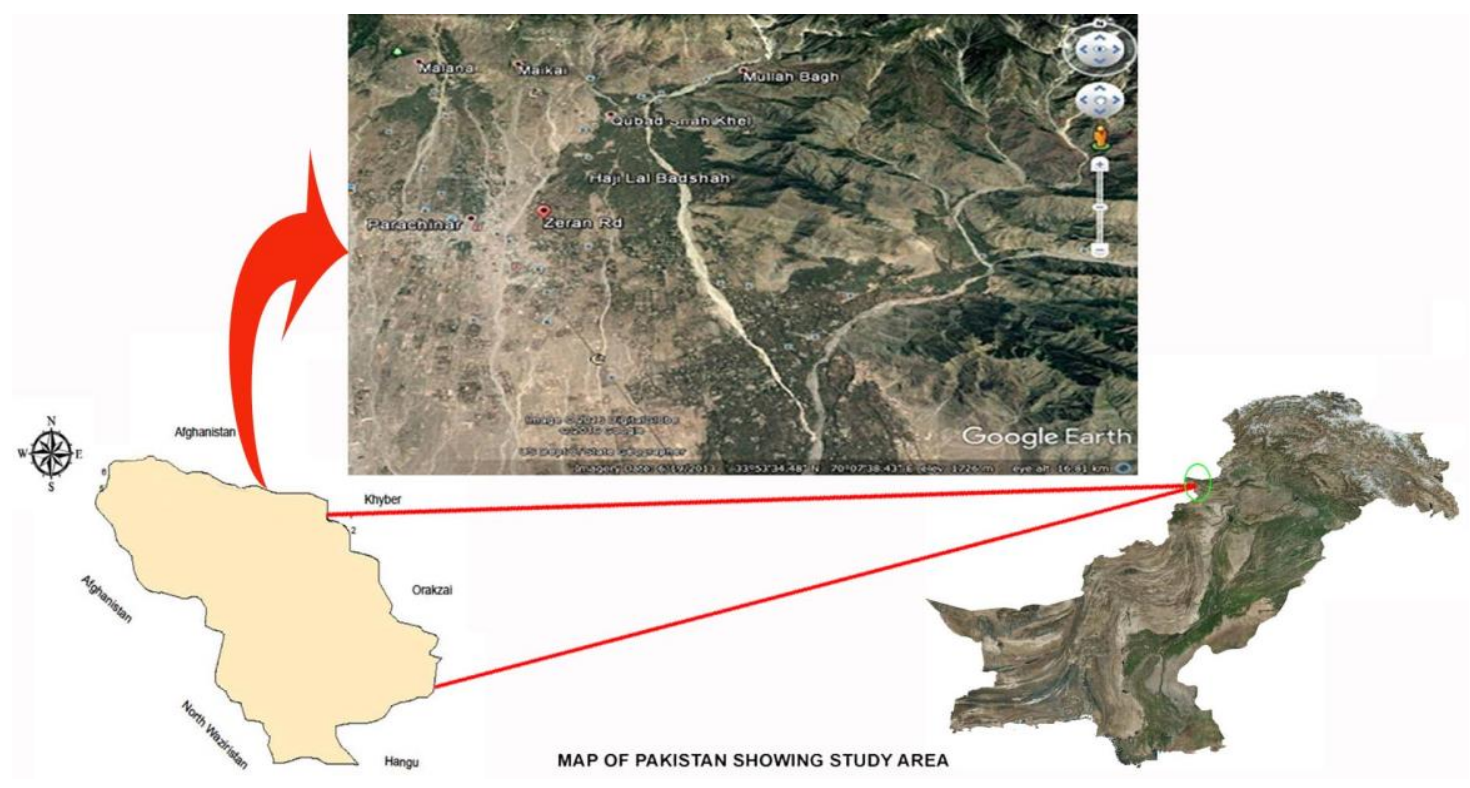

Figure 1. . Map of the Zeran valley (Border region of Pakistan and Afghanistan).

\section{Field sampling techniques for vegetation quantification}

During the summer season of 2016 to 2017, phytosociological techniques were used for vegetation assessment along edaphic and other related environmental transects (Laurance et al., 2004; Khan et al., 2012). The area was divided into seven different stations on the basis of floristic composition, physiognomy, topography and altitudinal variation (McMahon et al., 2011). Mature and least disturbed vegetation of the study area was focused (Laurance et al., 2004). A mixture of transect and quadrats method was frequently used. Square shape quadrats $1 \times 1 \mathrm{~m}^{2}, 5 \times 5 \mathrm{~m}^{2}$ and $10 \times 10 \mathrm{~m}^{2}$ for herbs, shrubs and trees respectively were laid in each station. The plant species were collected from respective habit type, vernacular names, family names and other relevant 
information were recorded in the field note books. The collected plant specimens were properly pressed, dried using blotting papers, poisoned and finally mounted on the standard herbarium sheets. All specimens were preserved in the Herbarium of Quaid-IAzam University, Islamabad, Pakistan for future reference. The specimens were identified with help of the Flora of Pakistan (Ali et al., 1972-2009; Ali and Qaiser, 1986, 1995-2010) and available literatures at Islamabad Herbarium, Quaid-I-Azam University and National Herbarium at National Agriculture Research Centre (NARC), Pakistan. The scientific names of all plant species were confirmed from the plant list website (http://www.theplantlist.org).

The quantitative vegetation attributes i.e., density, cover, frequency and their relative values were recorded. Importance Value Indices of species were also calculated (Curtis and McIntosh, 1950). Various environmental variables like grazing pressure, soil depth and condition, number of stumps, elevation and aspects were recorded with special concentration. Geographical co-ordinates of each site were noted using GPS. The community's names were based on ISA, species constancy and faithfulness.

\section{Soil sampling and analyses}

Since the top-soil soil contains greater nutrient concentration ad highest organic matter contents. Mostly roots biomass is accumulated throughout this soil profile (Vallés et al., 2015; Jobbágy and Jackson, 2001). Within each quadrat, soil samples were randomly collected from each microsite, and then mixed accordingly to make a unique pooled. Pebbles and wood pieces were removed. The samples were shad dried, sieved, air dried, grinded and analysed for the selective physico-chemical edaphic factors in a Fauji Fertilizer Company (FFC) limited farm advisory centre, Hasan Abdal, Pakistan. The soil texture was determined by the hydrometer method of particle-size analysis (Day, 1965). The Organic carbon (O.M) contents were analysed via (Nelson and Sommers, 1996) methodology and Nitrogen was measured following the semimicro Kjeldahl procedure of (Bremner and Mulvaney, 1982). Electric conductivity (E.C) was analysed in saturation extract using (Rhoades, 1982) protocol. Potassium and Phosphorus were analysed according to (Soltanpour, 1985), whilst Sodium was measuerd via (Rhoades and Miyamoto, 1990) methodology.

\section{Data statistical analyses}

The data obtained from field work needs to be examined in a statistical framework (Kent and Coker, 2002). It helps ecologists to analyse the effect of environmental factors, vegetation classification and mapping for conservation and management purposes (Anderson et al., 2006). Data of 252 quadrats (84 for each trees, shrubs and herbs species respectively) were alphabetically arranged in MS Excel spread sheet 2010. The utilities of PC-ORD version_5 i.e., Cluster Analysis (CA) and Indicator Species Analysis (ISA) were applied to classify plant communities (Dufrene and Legendre, 1997), analyse distribution pattern and identify indicators species respectively. CA brings stations with similar floristic composition close to each other (Sorensen, 1948; Dalirsefat et al., 2009). The ISA identified indicator plant species with statistical significance $(\leq .05)$ of each habitat type, defined by the environmental variable. It also constructed indicator values for each species using Monte Carlo techniques. Each species was evaluated for its ability to categorize among all the treatments of environmental variables and attributed to its suitable habitat type. ISA 
provided suggestions of how well the presence of a species would indicate a specific station or plant community (Dufrene and Legendre, 1997).

Mantel test as a utility of PCORD was used to estimate the strength of the relationship between species and environmental data matrices. These tests help to test hypothesis, whether variation in factors like aspect and elevation etc would have any impact on the diversity of plant species as well as communities qualitatively as well as quantitatively. The naming of plant communities was based on the indicator plant species, having significant $\mathrm{P}$ value $\leq 0.05$, identified by ISA, as recommended by Dufrêne and Legendre (1997). Beside this, constancy and fidelity level of the characteristics species of the communities were also checked for further authentication of indicator, to use in naming the communities (Malik and Husain, 2006).

\section{Ordination analyses for identification of ecological responsible gradients}

Ordination is a multivariate statistical method that summarizes communities data by constructing a low dimensional space in which similar samples and species come closer together along the specific environmental gradients complex and dissimilar ones goes further apart from each other (Gauch, 2010). Keeping the objectives in mind, we analysed plant species data with measured environmental variables in CANOCO (Ter Braak and Barendregt, 1986). Canonical Correspondence Analyses (CCA) is the most meaningful direct ordination gradient technique (Braak, 1988). It is widely used to examine environmental factors influence (Dufrene and Legendre, 1997). The CANOCRAW, utility of CANOCO was used to construct CCA plots of speciesenvironmental and community-environmental variables.

\section{Results}

\section{Species diversity and dominant species}

Preliminary findings confirmed total of 195 vascular plant species belongs to 144 genera of 60 Families in the study area (Table Al in the Appendix). The recorded 195 plant species belong to 144 genera and 60 families (Table Al). In which 3 and 5 species belongs pteridophytes and gymnosperms, whilst angiosperms dominating the area with 186 species. Within angiosperms, dicotyledons dominated the region having 160 members whilst 27 species were the representative of monocotyledons (see Appendix). The dominant species were evaluated on the basis of the IVI. The lower altitude $(1500-2000 \mathrm{~m})$ subtropical evergreen elements like Olea ferruginea (7.60\%) and deciduous Treelets species like Cotoneaster bacillaris (3.79) dominated the area. In the middle attitude (2000-2500 m) broad leaved evergreen, Quercus baloot $(8.63 \%)$ found to be dominant whilst at the higher elevational zone (2500-3000 m) moist temperate element and western Himalayan native species Quercus dilatata (17.11\%) and Cedrus deodara (6.37\%) forming close gregarious association. The forest thickness was positively correlated whilst species diversity and richness were negatively correlated along the elevational gradient in the study area. The lower xeric elevation was mostly occupied by habitat Daphne mucronata (8.58\%), Sophora mollis (12.17\%) and Berberis lyceum (7.99\%). On the other hand higher elevational zones were dominated by, Indigofera heterantha, plectranthus rugosus and Berberis parkeriana by $19.04 \%, 14.81 \%$ and $7.39 \%$ of IVI total weightage of 21 recorded shrub species. The forest ground flora was dominated by representatives of Poaceae includes; cynodon dactylon (7.73\%), Stipa sibirica (3.72\%), Setaria pumila (3.26), Piptatherum laterale 
(2.69\%), Apluda mutica (2.56\%), Agrostis vinealis (2.11\%) with associated species; Medicago sativa (6.16\%), Cirsium arvense (3.91\%) Oxalis corniculata $(2.71 \%)$ and Viola odorata (2.44\%) in 142 recorded herbs species (Appendix). The V. cardiostephanum was reported after122 years and confirms their occurance with a rarity in Pakistan. Harsukh, collected for the first time but in non-flowering stage (Fig. 6C). Our study re-confirms the occurrence of $V$. cardiostephanum in Pakistan. Its holotype Rechinger 35614 (W) belongs to Afghanistan. Hence, it is a narrow endemic to this ecotonal region of Pak-Afghan border, with a limited distribution; probably less than $100 \mathrm{~km}^{2}$. According to the IUCN red list categories and criteria it has been declared as Critically Endangered species.

\section{Community's classification}

The application of PC-ORD version-5 packages with 1,0 data gave rise to Cluster Analyses (CA); precisely divide the plant species into four major communities (Fig. 2). The communities' nomenclatures were based on the species constancy, fidelity level and Indicator Species Analyses (ISA). Each indicator species was studied under the influence of environmental variables. The Monte Carlo test result showed that; Nitrogen (N), Sodium $(\mathrm{Na})$, Soil texture (S.T) and altitude played significant role in communities' composition. The Monte Carlo test result shows the strength of the environment-species relationship. The first community; Elaeagnus angustifolia-Rosa chinensis-Seriphidium kurramense was found at the lower altitude. The habitat of this community was mostly xeric. The second community; Platanus orientalis-Rosa moschata-Epilobium hirsutum found, where mostly agricultural practices were noticed. The third community; Quercus baloot-Jasminum auriculatum-Foeniculum vulgare and fourth communities Quercus dilatata-Hedera nepalensis-Calamintha umbrosa were found at the high elevation (Table 1).

Table 1. Detail information of the indicator species of the all communities along with fidelity level, constancy classes and Indicator species analyses

\begin{tabular}{|c|c|c|c|c|c|c|c|c|}
\hline \multirow{2}{*}{ S No. } & \multirow{2}{*}{ Indicator species } & \multirow{2}{*}{ Com } & \multicolumn{2}{|c|}{ Constancy } & \multirow{2}{*}{ F. C. } & \multirow{2}{*}{ Var } & \multirow{2}{*}{ I.V } & \multirow{2}{*}{$\mathbf{P} *$} \\
\hline & & & C.C & $\mathrm{C} \%$ & & & & \\
\hline \multirow{2}{*}{1} & \multirow{2}{*}{ Elaeagnus angustifolia } & \multirow{2}{*}{$1^{\text {st }}$} & \multirow{2}{*}{$\mathrm{C} 4$} & \multirow{2}{*}{68.75} & \multirow{2}{*}{72.3} & $\mathrm{~N}$ & 47 & 0.05 \\
\hline & & & & & & S.T & 46 & 0.01 \\
\hline 2 & Rosa chinensis & $1^{\text {st }}$ & $\mathrm{C} 1$ & 12.5 & 100 & $\mathrm{~K}$ & 47 & 0.02 \\
\hline \multirow{2}{*}{3} & \multirow{2}{*}{ Seriphidium kurramense } & \multirow{2}{*}{$1^{\text {st }}$} & \multirow{2}{*}{ C3 } & \multirow{2}{*}{43.75} & \multirow{2}{*}{100} & $\mathrm{~N}$ & 49 & 0.04 \\
\hline & & & & & & O.M & 13 & 0.04 \\
\hline 4 & Platanus orientalis & $2^{\text {nd }}$ & $\mathrm{C} 2$ & 26.09 & 61.02 & $\mathrm{Na}$ & 25.8 & 0.0302 \\
\hline \multirow{2}{*}{5} & \multirow{2}{*}{ Rosa moschata } & \multirow{2}{*}{$2^{\text {nd }}$} & \multirow{2}{*}{$\mathrm{C} 1$} & \multirow{2}{*}{8.7} & \multirow{2}{*}{67.61} & $\mathrm{Na}$ & 66.3 & 0.001 \\
\hline & & & & & & $\mathrm{EC}$ & 19.7 & 0.0562 \\
\hline 6 & Epilobium hirsutum & $2^{\text {nd }}$ & $\mathrm{C} 1$ & 4.35 & 100 & $\mathrm{Na}$ & 33.3 & 0.0358 \\
\hline 7 & Quercus baloot & $3^{\text {rd }}$ & $\mathrm{C} 2$ & 29.17 & 50.52 & $\mathrm{pH}$ & 56.1 & 0.0528 \\
\hline 8 & Jasminum auriculatum & $3^{\text {rd }}$ & $\mathrm{C} 1$ & 12.5 & 100 & $\mathrm{pH}$ & 33.3 & 0.0386 \\
\hline \multirow{2}{*}{9} & \multirow{2}{*}{ Foeniculum vulgare } & \multirow{2}{*}{$3^{\text {rd }}$} & \multirow{2}{*}{$\mathrm{C} 1$} & \multirow{2}{*}{4.17} & \multirow{2}{*}{100} & $\mathrm{Na}$ & 33.3 & 0.032 \\
\hline & & & & & & $\mathrm{EC}$ & 20 & 0.0526 \\
\hline 10 & Quercus dilatata & $4^{\text {th }}$ & C3 & 52.38 & 100 & $\mathrm{~K}$ & 33.7 & 0.0196 \\
\hline 11 & Hedera nepalensis & $4^{\text {th }}$ & $\mathrm{C} 1$ & 4.76 & 100 & $\mathrm{ST}$ & 33.3 & 0.0308 \\
\hline \multirow{2}{*}{12} & \multirow{2}{*}{ Calamintha umbrosa } & \multirow{2}{*}{$4^{\text {th }}$} & $\mathrm{C} 1$ & 1429 & & $\mathrm{~K}$ & 43.9 & 0.011 \\
\hline & & & & 14.27 & 10.01 & $\mathrm{Na}$ & 32.8 & 0.0196 \\
\hline
\end{tabular}

Com = community, C.C = Constancy class, $\mathrm{C} \%=$ Constancy $\%, F \cdot C=$ Fidelity class, Var $=$ Variables, $\mathrm{I} . \mathrm{V}=$ Indicator Value, $\mathrm{P}^{*}=$ significant value 


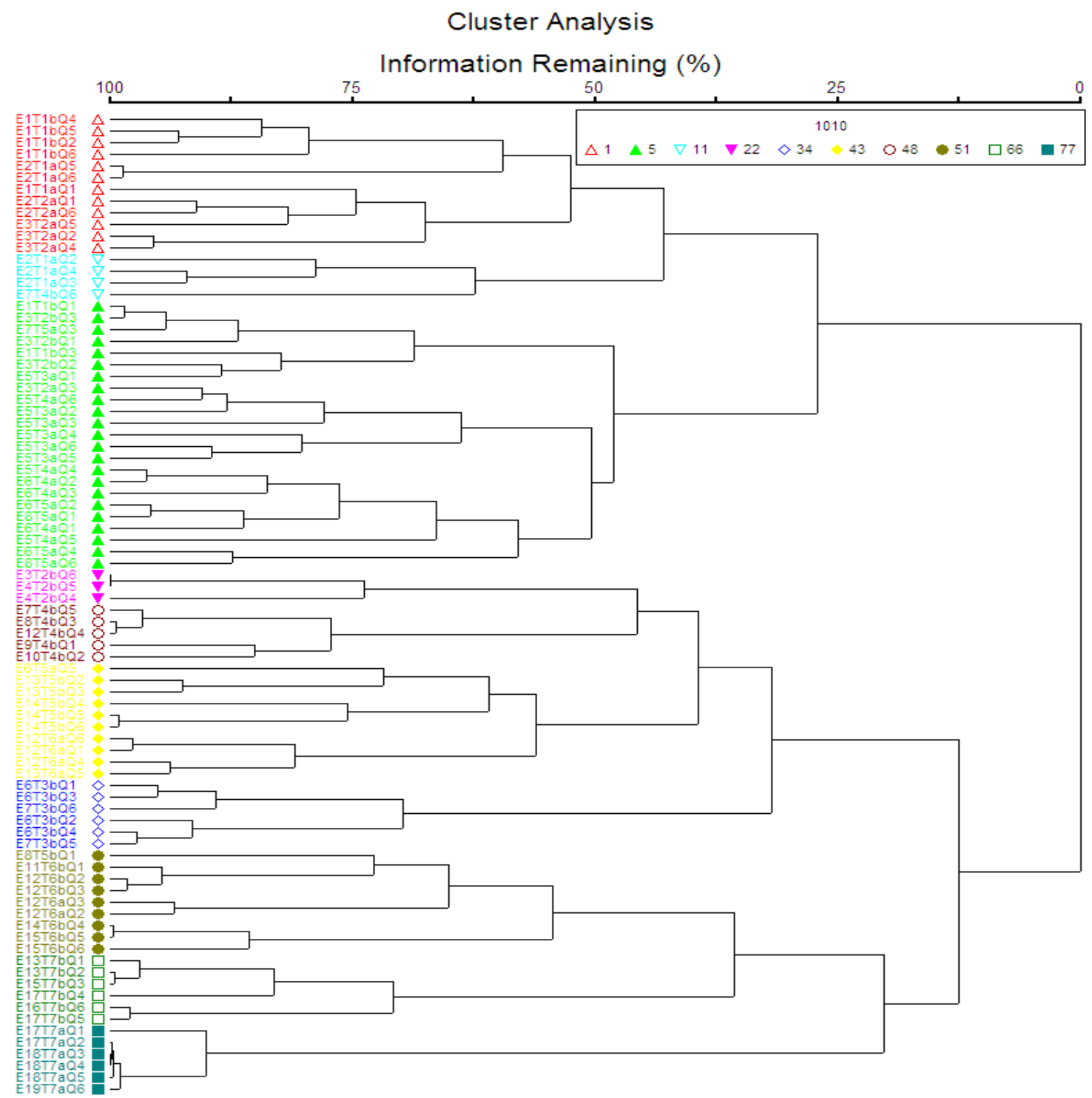

Figure 2. Cluster Analysis classifying the study sites into four communities.

\section{Elaeagnus angustifolia - Rosa chinensis - Seriphidium kurramense community}

The application of CA and TWCA based on Sorenson Similarity Index, a total of 48 releves clustered in this community. It was found at the elevation range of 1550-1900 m above sea level (a.s.l). The name was given based on significant indicator species $\left(\mathrm{P}^{*}\right.$ value $\leq 0.05)$ i.e., Elaeagnus angustifolia, Rosa chinensis and Seriphidium kurramense respectively (Table 1). Impacts of edaphic factors were also analysed and found that higher Nitrogen and Potassium concentration and medium Organic matter were the most prominent driving environmental variables in determination of these indicator species (Fig. 5). Moreover, these species have higher constancy fidelity within this community (Table 1). The concentration of $\mathrm{N}$ and $\mathrm{pH}$ in this community is higher as it comprises of the cultivated land, where use of fertilizers like Di-Ammonium Phosphate (Muthuramkumar et al.), Nitro-Phos (NP) and Potassium sulphate are repeatedly used for higher yields. Based on IVI values the dominant tree species includes Robinia 
pseudoacacia, Punica granatum and Populus nigra. Amongst the shrubby layer Daphne mucronata and Berberis lycium were the dominant whereas in the herbaceous layer Cynodon dactylon, Sanguisorba minor and Dichanthium annulatum were reported as dominated species of this community.

Being located at lower elevation numbers of anthropogenic activities i.e., deforestation for fuel and fodder purposes, over grazing and agricultural land expansion are the main threats to the vegetation of this community. It was easily accessible to vicinity of human settlement to utilize the local plant resources. The physio-chemical analyses of this community revealed that $\mathrm{pH}$ ranges from 6.8 to 7.8, Nitrogen (0.032$0.87 \%$ ), Sodium (0.5-1.4 mmolc/100 g), Electrical Conductivity (0.17-0.33 dS/m), Phosphorous (1-4 ppm), Potassium (106-420 ppm) and Organic matter (0.51-1.39\%).

\section{Platanus orientalis - Rosa moschata - Epilobium hirsutum community}

This community was found at the middle elevation $(1950-2300 \mathrm{~m})$ of the valley. It hosts 84 different quadrats. The characteristic species of tree, shrub and herb layers were Platanus orientalis, Rosa moschata and Epilobium hirsutum respectively. Sodium and $\mathrm{EC}$ were the main environmental variables determining the indicator species of this community (Fig. 5). We observed that Rosa moschata was found in higher while other indicator species observed at a moderate concentration of Sodium and Electrical Conductivity respectively. The indicator species was found with relatively lower constancy level and higher fidelity level within this community (Table 1). The other important tree species present were Populus nigra, and Diospyros lotus. These species were cultivated, therefore gains dominancy in this community as well. Abundant shrub species reported were Sambucus nigra, Rubus fruticosus and Indigofera heterantha. Dominant herbs species were Medicago sativa and Impatiens edgeworthii in this community.

Agricultural practices were found as the top disturbing elements in this community. Analysing of soil showed that $\mathrm{pH}$ ranges from 7.1 to 7.9 , Nitrogen $(0.043-0.078 \%)$, Sodium (0.6-1.5 mmolc/100 g), Electrical Conductivity (0.15-1.18 dS/m), Phosphorous (2-6 ppm), Potassium (84-900 ppm) and Organic matter (0.69-1.25\%).

\section{Quercus baloot - Jasminum auriculatum - Foeniculum vulgare community}

Based upon Sorenson index of similarity measurement this community was established relatively at the higher elevation, i.e., 2350-2780 m. Vegetation of this community was dominated by woody plants. Diagrammatic presentation of cluster dendogram show total 72 releves clustered together in this community. The principle indicator species of this community were Quercus baloot, Jasminum auriculatum and Foeniculum vulgare. The important environmental variables responsible for the community establishment were slightly higher $\mathrm{pH}$, moderate Sodium and higher concentration of EC (Fig. 5). All the characteristic species of this community show higher level of faithfulness (Table 1). This community comprises of a thick forest dominated by ever green tree species i.e., Quercus semicarpifolia, Olea ferruginea and deciduous tree species like Celtis caucasica. Indigofera heterantha, Plectranthus rugosus and Sophora mollis were the dominant shrubs. Piptatherum laterale and Thymus linearis were the dominant herb species.

Fodder, fuel wood, chopping and grazing were observed as main anthropogenic activities disturbing the natural vegetation equilibrium. Soil analyses of this community 
indicates that $\mathrm{pH}$ ranges from 6.8 to 7.8 , Nitrogen $(0.048-0.079 \%)$, Sodium $(0.3$ $2.4 \mathrm{mmolc} / 100 \mathrm{~g})$, Electrical Conductivity (0.07-1.33 dS/m), Phosphorous (2-10 ppm), Potassium (42-560 ppm) and Organic matter (0.76-1.26\%).

\section{Quercus dilatata - Hedera nepalensis - Calamintha umbrosa community}

This was the community of highest elevation range, that is $2800-3000 \mathrm{~m}$ a.s.1. It was represented by 63 quadrats. The analysis inveterate that; Quercus dilatata, Hedera nepalensis and Calamintha umbrosa were the strongest indicator species with a $\mathrm{p}$ values $<0.05$, under the influence of high Potassium and moderate Sodium concentration (Fig. 5). The characteristic species showed high fidelity and moderate constancy level (Table 1). This was tree dominating community comprised of the principle indicator of moist temperate vegetation i.e., Cedrus deodara, Quercus baloot and Pinus brutia as dominant tree species. Dominant shrub species were Indigofera heterantha, Plectranthus rugosus and Berberis parkeriana. This community has slightly lower species richness in comparison to the other communities. Thymus linearis and Apluda mutica were dominating the herbaceous layer of this community.

Soil depth was shallow, due to rugged topography and steep slopes. Higher grazing pressure make this community very prone for soil erosion. Lower temperature prevails throughout the year. These condition results low plant species diversity. Medicinal plant collectors for commercial purposes were the major anthropogenic activities. Large No of stumps were reported as people collect wood for timber and fuel purposes mainly from this elevation range. Physio-chemical analyses revealed $\mathrm{pH}$ ranges from 7.2-8, Nitrogen (0.052-0.072\%), Sodium (0.-1.4 mmolc/100 g), Electrical Conductivity (0.08$0.28 \mathrm{dS} / \mathrm{m})$, Phosphorous (2-6 ppm), Potassium (60-8690 ppm) and Organic Matter $(0.15-1.12 \%)$. Due to thick forest layer soil texture of this community was sandy clay loam.

\section{Direct environmental gradient analyses}

The plant and environmental data treatment via CCA identified the core factors; showing high significant p-value $<0.002$. The CCA bi-plot showed that both vegetation variations and communities' variations were mainly driven by; stumps, grazing pressure, Phosphorous, Sodium and Nitrogen (Table 2). The CCA ordination procedures for species and communities (Figs. 3, 4 and 5) indicated that 1st axis strongly correlated with altitude and partially with $\mathrm{pH}$; the $2^{\text {nd }}$ axis was mainly correlated with stumps (due to immense deforestation), high concentration of sodium and strong EC; $3^{\text {rd }}$ quadrat correlated with high Phosphorous and medium organic matter (O.M) whilst the $4^{\text {th }}$ axis was under the immense grazing pressure (Figs. 3 and 4). Similarly stations CCA bi-plot (Fig. 5) demonstrated clear reflection of altitudinal and latitudinal gradient complexes of the region. The $1^{\text {st }}$ and $2^{\text {nd }}$ community were clustered at the lower altitude. Moreover, it also describes stations of woody and evergreen vegetation was mostly found at the higher elevation. The physiographic and geomorphologic gradient complexes describes that depth soils and sunlight exposures loving vegetation were frequently distributed at lower parts whilst relatively thin soils an shad loving species favoured the high elevated habitats. The sum of all Eigen value Monte Carlo test were 14.312. The $1^{\text {st }}$ axis eigen value was quite high (0.469), which showed the slope in spreading species along with the axis. The $1^{\text {st }}$ axis cumulative percentage of Species-environment relation was $21.6 \%$ 
of total unexplained variance. This value of $4^{\text {th }}$ axis was the highest with $65.1 \%$ (Table 2).

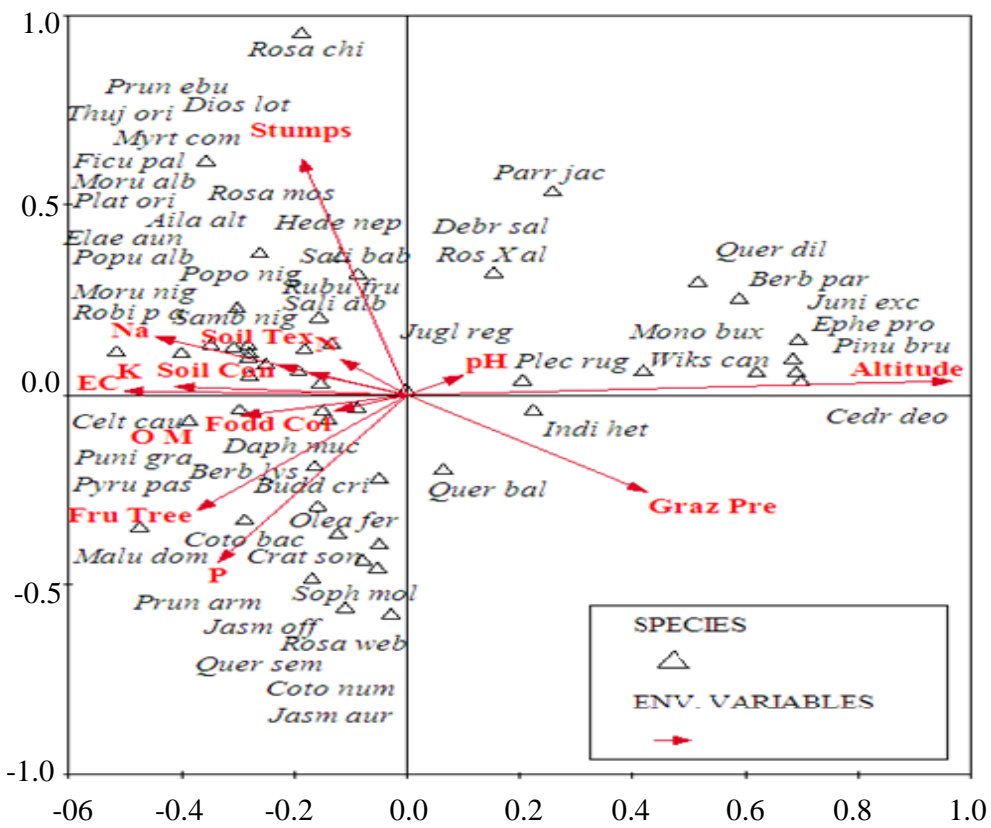

Figure 3. CCA diagram showing distribution trees and shrubs species along the environmental gradients. $P=$ Phosphorous, $N a=$ Sodium, $K=$ Potassium, $O M=$ Organic Matter, Soil Tex $=$ Soil Texture, N= Nitrogen and EC = Electric Conductivity, Fru tree $=$ Fruit trees, Soi Tex $=$ Soil texture, Graz Pre = Grazing pressure, Soil con= Soil Condition

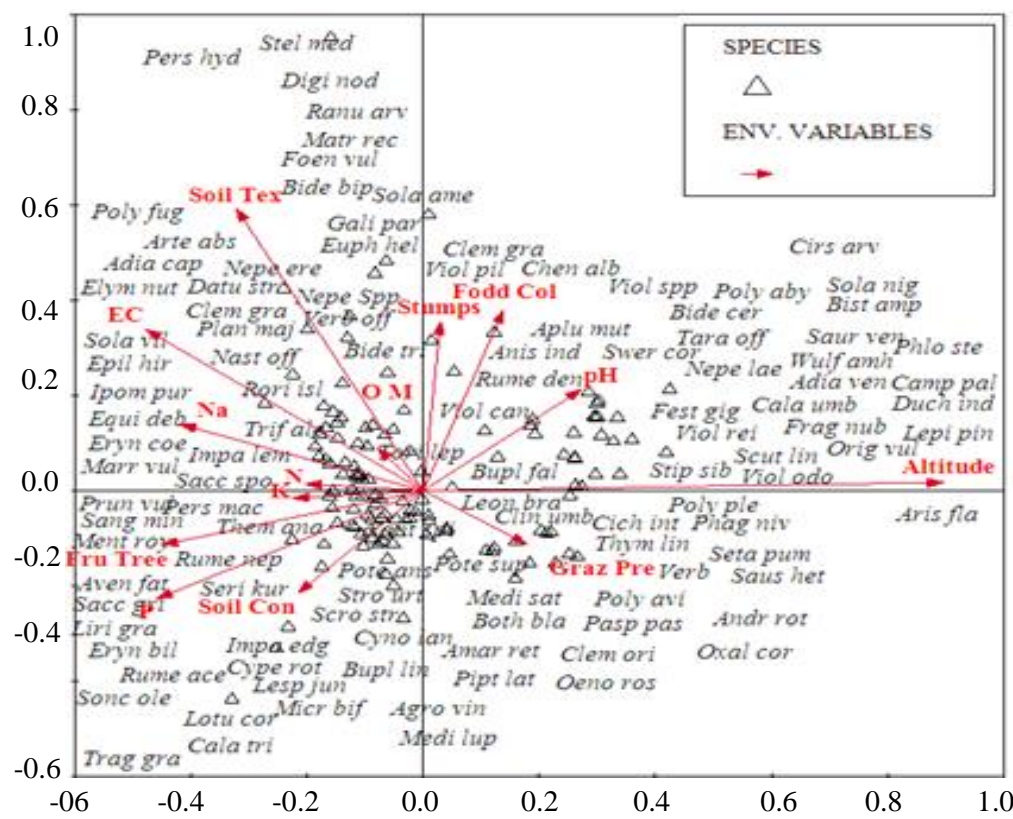

Figure 4. CCA diagram showing distribution herbs species along the environmental gradients. $P=$ Phosphorous, $N a=$ Sodium, $K=$ Potassium, $O M=$ Organic Matter, Soil Tex = Soil Texture, $N=$ Nitrogen and EC $=$ Electric Conductivity, Fru tree $=$ Fruit trees, Soi Tex $=$ Soil texture, Graz Pre $=$ Grazing pressure, Soil con $=$ Soil Condition 


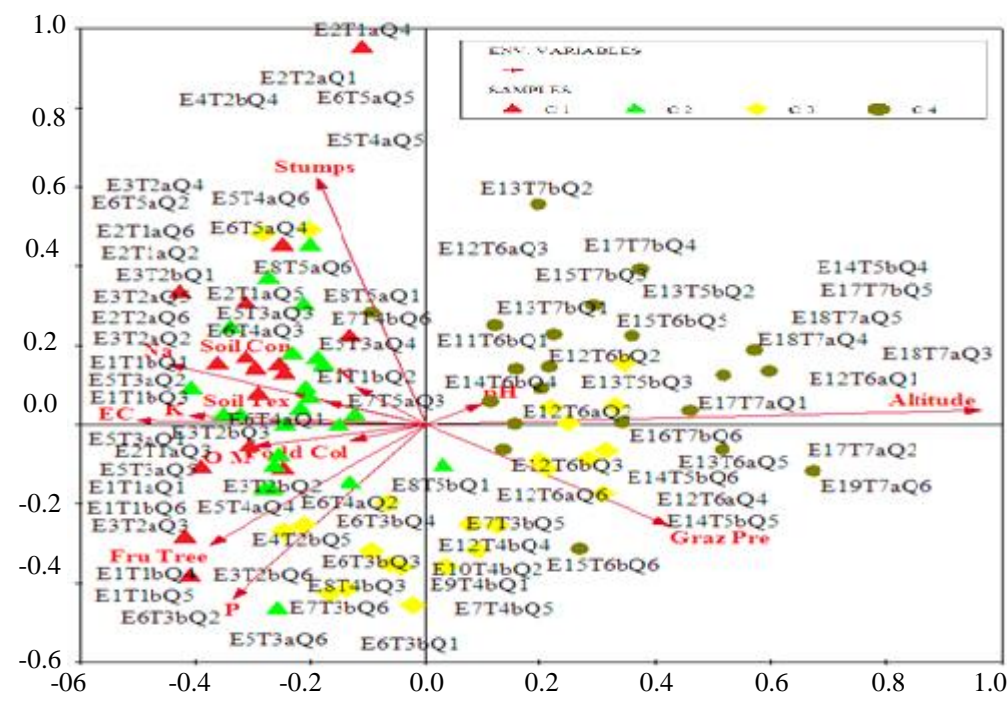

Figure 5. CCA diagram showing distribution selected stations along the environmental gradients. $P=$ Phosphorous, $N a=$ Sodium, $K=$ Potassium, $O M=$ Organic Matter, Soil Tex $=$ Soil Texture, $N=$ Nitrogen and EC $=$ Electric Conductivity, Fru tree $=$ Fruit trees, Soi Tex $=$ Soil texture, Graz Pre = Grazing pressure, Soil con $=$ Soil Condition, $C 1=$ Community $1^{\text {st }}, C 2=$ Community $2^{\text {nd }}, C 3=$ Community $3^{\text {rd }}$ and $C 4=$ Community $4^{\text {th }}$

Table 2. Summary of the CCA bi-plot four axes of Monte Carlo test for the ecotonal vegetation using IVI data

\begin{tabular}{c|c|c|c|c|c}
\hline Axes & 1 & 2 & 3 & 4 & Total inertia \\
\hline Eigen values & 0.469 & 0.394 & 0.288 & 0.262 & 14.312 \\
\hline Species-environment correlations & 0.903 & 0.880 & 0.909 & 0.836 & \\
\hline & \multicolumn{5}{c}{ Cumulative percentage } \\
\hline Variance of species data & 3.3 & 6.0 & 8.0 & 9.9 & \\
\hline Species-environment relation & 21.6 & 39.7 & 53.0 & 65.1 & 14.312 \\
\hline Sum of all eigen values & & & & & 2.170 \\
\hline Sum of all canonical eigen values & & & \multicolumn{3}{c}{ Test of significance of all canonical axes } \\
\hline $\begin{array}{c}\text { Summary of Monte Carlo test } \\
\text { (499 permutations under reduced model) }\end{array}$ & 0.469 & \multicolumn{2}{c}{ Trace } & 2.473 \\
\hline Eigen value & 2.539 & \multicolumn{2}{c}{ F-ratio } & 1.675 \\
\hline F-ratio & 0.002 & P-value & 0.002 \\
\hline P-value & \multicolumn{2}{c|}{}
\end{tabular}

\section{Discussion}

Biological assemblages could evaluate significantly the deteriorative impacts of anthropogenic activities on natural ecosystems (Kusnierz et al., 2015). Ecotones can be differentiated on the bases of the sharpness of their communities (Lloyd et al., 2000). The most appropriate causes are; sharp climatic gradient, elevation, invasion of dominant, steep topography and environmental factor especially human influences (Walker et al., 2003; Casalini, 2017). Results strongly support our hypothesis to have unique indicator vegetation at Ecotonal Zone and edaphological factors affecting 
community composition. A total of 195 belongs to 60 families of vascular plant species, were reported in varied ecological zones of the valley (Appendix). Altitude was one of the most important determinants, influencing directly species distribution; because it governs the micro climate of the habitats (Casalini, 2017; Singh et al., 2009). In the lower altitude (1500-2000 m) subtropical evergreen elements like Olea ferruginea (7.60\%) in an association with deciduous Treelets species Cotoneaster bacillaris (3.79) were recorded as dominated. In the middle attitude $(2000-2500 \mathrm{~m})$ broad leaved evergreen species, Quercus baloot (8.63\%) whilst moist temperate element and western Himalayan native species Quercus dilatata (17.11\%) and Cedrus deodara (6.37\%) at the elevation of 2500-3000 m were reported as dominant. Daphne mucronata (8.58\%), Sophora mollis (12.17\%) and Berberis lyceum (7.99\%, sub-tropical indicator) dominated the lower xeric elevation, whilst Indigofera heterantha $(19.04 \%$, ,) plectranthus rugosus (14.81\%) and Berberis parkeriana (7.39\%) find as dominant shrub species. The herbaceous flora was dominated mostly Poaceae members; cynodon dactylon (7.73\%), Stipa sibirica (3.72\%), Setaria pumila (3.26), Piptatherum laterale (2.69\%), Apluda mutica (2.56\%), Agrostis vinealis (2.11\%) along with Medicago sativa (6.16\%), Cirsium arvense (3.91\%) Oxalis corniculata $(2.71 \%)$ and Viola odorata (2.44\%) in 142 recorded herbs species (Appendix). The $V$. cardiostephanum occurrence was reconfirmed after Harsukh (122 years later) and who collected it in non-flowering stage (Fig. 6C). We collect it in flowering stage and occupying less than $100 \mathrm{~km}^{2}$, so applying IUCN category and criteria; declared it as its holotype Rechinger 35614 (W) belongs to Afghanistan. Hence, it is a narrow endemic to this ecotonal region of PakAfghan border, with a limited distribution; probably less.

The species richness and Diversity Index were optimum at middle elevations (2000$2400 \mathrm{~m}$ a.s.l) as compare to the lower (1500-150 $\mathrm{m}$ a.s.l), and higher altitudes due to various pressures and xeric conditions at these areas. Reporting moist indicator climatic species like; Cedrus deodara, Indigofera heterantha, Bistorta amplexicaulis and Trifolium repen (Appendix) in the high elevation is supported by Saima et al. (2009) and Ahmed et al. (2006) studies. The gradual decreasing in species richness along the increasing altitude is considered as a general pattern Shaheen et al. (2011, 2012). Such phenomena of species distribution have also been reported from other mountainous locations using more or less same techniques, i.e., Anderson et al. (2006), Ahmad et al. (2015) and Haq et al. (2017). The micro climatic conditions of the valley vary from subtropical to cool temperate zone is in accordance to and Shen et al. (2015) and Zhou et al. (2018). The vegetation of Irano-Toranian and Western Himalayan types for example Parrotiopsis jacquemontiana is one of such indicator from the Current location as well. Comparison with previous researches in the adjacent areas indicates similar vegetation zones Khan and Ahmad (2015), Khan et al. (2016) and Haq et al. (2015a).

The multivariate statistical analysis via PCORD V-5 software sorted out the vegetation into 4 plant communities (Fig. 2) on the bases of indicator plant species. Approach to the communities naming based on statistical approaches, specifically Indicator Species Analysis in conjunction with fidelity (faithfulness) and constancy measurements of Bergmeier (2002) is one of the technical feature of our finding. The use of indicator species to determine environmental conditions and community types is an emerging technique in vegetation ecology for both theoretical and applied purposes. This use of multispecies environmental or ecological indications instead of single or repetitive indicator has enormously contributed in the bio-indication system and its reliability (Carignan and Villard, 2002; Niemi and McDonald, 2004; Butler et al., 2012; 
Rahman et al., 2019). The characteristic species of each community was confirmed through Indicator Species Analyses, Species fidelity Level and constancy classes. Similar procedure for communities composition were also adopted by Shaheen et al. (2011) Khan et al. (2012), Khan (2012), Ahmad et al. (2016), Bano et al. (2017), Pharswan and Mehta (2010) and Ilyas et al. (2012) in their respective research. Indicator species analyses revealed that Nitrogen, Phosphorous, Sodium, EC and $\mathrm{pH}$ were the strongest and significant edaphic factors $(\mathrm{p} \leq 0.05)$ for the constitutions plant communities and determination of indicator species (Table 1). Khan et al. (2016) used the same method with unique results from Thandiani Sub-Forest Division of the Western Himalayas. Soil factors influences over plant distribution in the ecotonal region agreed with the previous studies of El-Keblawy et al. (2015) and Grellier et al. (2014).

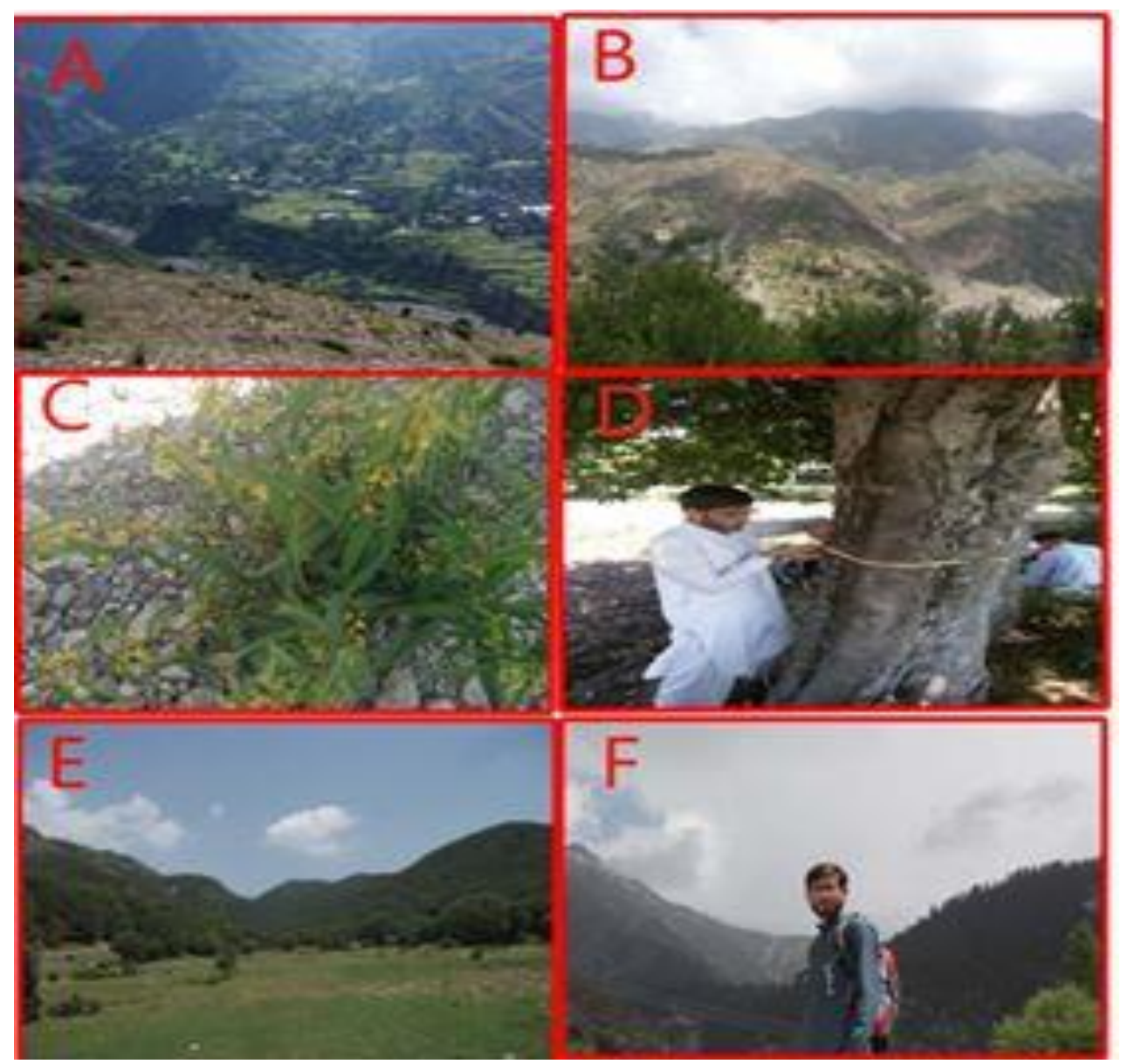

Figure 6. Pictorial view of the ecotonal region, (A) settlements with agricultural practices, $(B)$ South facing Barren mountains range $(C)$ Vincetoxicum cardiostephanum in flowering stage (D) measuring DBH of Crataegus songarica, (E) Quercus dilatata thick forest and pastures zone, $(F)$ Snow covered high elevated mountains peak

CANOCO version 4.5 was used to analyse the effect of biotic and abiotic factors on species composition, diversity and community structure (Figs. 3, 4 and 5). Use of these Software packages can be seen in the studies of Brown and Bezuidenhout (2005) and Khan et al. (2012b). The elevation, longitude and latitude were responsible for microclimatic variations. Dense vegetation was observed on the north facing slopes as 
compared to south facing slopes in the high elevation of the valley. The environmental gradients like elevation, soil conditions, grazing pressure and soil texture clearly indicates strong impacts on species diversity and composition of the region (Figs. 4 and 5; Table 2). Soil depth decreases with the high elevation due to steep slopes in areas where soil erodes during rainy seasons. The Organic matter concentration in the lower region (Figs. 3, 4 and 5) is quite high, it was the prime factor retaining higher species diversity and thick vegetation cover, is in accordance to the Casalini (2017) and BaoLiang et al. (2009) because it is reliable to retain greater humidity and moisture concentration in landform (Pei et al., 2010). Ecologists recommended such ecosystems to support higher biodiversity and combat with climatic challenges. CCA bi-plot also revealed that species were highly sensitive to EC, Phosphorous and sodium (Fig. 3 and 4). These findings are in agreements with Khan et al. (2013) and Shaukat et al. (2014). Furthermore, increasing herbaceous vegetation along the elevation gradients indicates the positively correlation with eco-physiological stresses along the increasing altitude. The physiographic elements altitudinal range variations and edaphic factors have great effect on vegetation structure and its distribution pattern (Fig. 5). Plant species restricted to a particular habitat due to the availability of their requirements and optimum environmental factors. These factors clearly change the community structure and their distribution from point to point. Now a-days such studies have been adopted by numerous of ecologists and environmentalists to correlate the communities with the environmental factors (Chawla et al., 2008 and Khan et al., 2015).

Amongst the anthropogenic stimuli (counting stumps) repeated fuel-wood chopping is considered the major factor having huge impacts on the structure of the vegetation and results declining and almost disappearance of large old trees (Fig. 3 and 4). The most preferred species for fuel wood consumptions includes; Quercus dilatata, $Q$. baloot, Olea ferruginea, Morus nigra and M. alba. The greater wood extraction level than the carrying capacity causes a proportional changes in structure and community composition. Moreover, harvesting scenarios also increase ecological impacts. Once they become lost, large gap will be created; so forest fragmentation will be enhanced and probably susceptibility to invasion will be promoted (Rüger et al., 2008); and will inhibit the native seedlings regeneration (Cochrane, 2003). The grazing pressure has negatively affected the species diversity and vegetation structure (Fig. 3 and 4), this happen because over grazing can alter soil chemistry and also make it prone for the erosion (Rooney and Waller, 1998). The heavy and uncontrolled grazing and trampling by large amount of cattle on daily by local nomads is alarming situation. For best management legislation, the regeneration patterns and the main governing factors should be addressed (Wangda, 2003). Moreover, subsequent soil erosion and harsh climate during winter season also had catastrophic affect. The dense lush green vegetation of the region are now slowly and steadily replaced by stripped steep ridges, with increasing number of houses, roads and terracing fields. Our finding suggests priorities for the biodiversity conservation via indicator species approaches. Border Area of Afghanistan is geopolitically zone of tension that makes it an Ecotonal territory with rich diversity and must be evaluated taxonomically for probable new species. Recently, ecotones have gained greater attention because also species has narrow ecological amplitude (Silva and Souza, 2018; Corenblit et al., 2011) and expected future climatic changes could affect ecotonal vegetation very strongly (Camarero et al., 2017; Gebrekirstos et al., 2014). 


\section{Conclusion}

The species distribution, communities composition using edaphic and environmental variables contributed valuable information for understanding ecotonal vegetation. We concluded that fragile vegetation of this sensitive region is under tremendous pressure due to diverse anthropogenic activities. It enhanced understanding of phyto-diversity that could potentially lead for conservation, especially in the perspective of anthropogenic impacts. The robustic multivariate statistical tools recognized indicator for micro-climatic and micro-ecological zonation. Results could be improved further if; soil moisture contents studied along the topographical gradient. It will ultimately enhance edaphological and geomorphological role for vegetation management and conservation strategies in landscape ecology. Moreover, presence of endemic species required detail taxonomic and micro-ecological investigation.

Acknowledgments. The authors would like to extend their sincere appreciation to the Deanship of Scientific Research at King Saud University for its funding to this Research group NO (RG-1435-014).

\section{REFERENCES}

[1] Ahmad, H., Khan, A. A. (2004): Conservation and sustainable use of medicinal and aromatic plants of Pakistan. - Proceedings of the International Workshop held in Islamabad, December 2, 2003.

[2] Ahmad, H., Öztürk, M., Ahmad, W., Khan, S. M. (2015): Status of Natural Resources in the Uplands of the Swat Valley Pakistan. - In: Öztürk, M. et al. (eds.) Climate Change Impacts on High-Altitude Ecosystems. Springer, Cham, pp. 49-98.

[3] Ahmed, M., Husain, T., Sheikh, A. H., Hussain, S. S., Siddiqui, M. F. (2006): Phytosociology and structure of Himalayan forests from different climatic zones of Pakistan. - Pakistan Journal of Botany 38(2): 361.

[4] Ali, S., Khatoon, S. (1982): Genus Vincetoxicum von Wolf (Asclepiadaceae) in Pakistan. - Pakistan Journal of Botany 14: 61-68.

[5] Ali, S., Nasir E., Qaiser M. (1972-2009): Flora of Pakistan. - Pakistan Agricultural Research Council and The University of California, USA.

[6] Ali, S. I., Qaiser, M. (1986): A phytogeographical analysis of the phanerogams of Pakistan and Kashmir. - Proceedings of the Royal Society of Edinburgh, Section B: Biological Sciences 89: 89-101.

[7] Ali, S. M., Qaiser M. (1995-2010): Flora of Pakistan. - Fakhri Printing Press, Karachi.

[8] Anderson, M. J., Ellingsen, K. E., McArdle, B. H. (2006): Multivariate dispersion as a measure of beta diversity. - Ecology Letters 9(6):.683-693.

[9] Arellano, G., Umaña, M. N., Macía, M. J., Loza, M. I., Fuentes, A., Cala, V., Jørgensen, P. M. (2017): The role of niche overlap, environmental heterogeneity, landscape roughness and productivity in shaping species abundance distributions along the Amazon-Andes gradient. - Global Ecology and Biogeography 26: 191-202.

[10] Bano, S., Khan, S. M., Alam, J., Alqarawi, A. A., Abd_Allah, E. F., Ahmad, Z., Rahman, I. U., Ahmad, H., Aldubise, A., Hashem, A. (2017): Eco-floristic studies of the Beer Hills along the Indus River in the districts Haripur and Abbottabad, Pakistan. - Saudi Journal of Biological Sciences. https://doi. org/10.1016/j.

[11] Bao-Liang, C. H. I., Cheng-Si, B. I. N. G., Walley, F., Yates, T. (2009): Topographic indices and yield variability in a rolling landscape of western Canada. - Pedosphere 19(3): 362-370.

[12] Bergmeier, E. (2002): The vegetation of the high mountains of Crete a revision and multivariate analysis. - Phytocoenologia 32(2): 205-249. 
[13] Biondi, E. (2011): Phytosociology today: methodological and conceptual evolution. Plant-Biosystems - An International Journal Dealing with all Aspects of Plant Biology 145(suppl. 1): 19-29.

[14] Braak, C. J. (1988): CANOCO — an extension of DECORANA to analyze speciesenvironment relationships. - Plant Ecology 75(3): 159-160.

[15] Bremner, J. M., Mulvaney, C. (1982): Nitrogen - Total 1. - In: Page, A. L. et al. (eds.) Methods of Soil Analysis. Part 2: Chemical and Microbiological Properties. SSSA, Madison, WI, pp. 595-624.

[16] Brown, C. D., Johnstone, J. F. (2012): Once burned, twice shy: Repeat fires reduce seed availability and alter substrate constraints on Picea mariana regeneration. - Forest Ecology and Management 266: 34-41.

[17] Brown, L. R., Bezuidenhout, H. (2005): The vegetation of the farms Ingleside and Welgedacht of the Mountain Zebra National Park, Eastern Cape. - Koedoe 48(2): 23-42.

[18] Butler, S. J., Freckleton, R. P., Renwick, A. R., Norris, K. (2012): An objective, niche-based approach to indicator species selection. - Methods in Ecology and Evolution 3(2): 317-326.

[19] Byrne, K. M., Adler, P. B., Lauenroth, W. K. (2017): Contrasting effects of precipitation manipulations in two Great Plains plant communities. - Journal of Vegetation Science 28(2): 238-249.

[20] Camarero, J. J., Linares, J. C., García-Cervigón, A. I., Batllori, E., Martínez, I., Gutiérrez, E. (2017): Back to the future: the responses of alpine treelines to climate warming are constrained by the current ecotone structure. - Ecosystems 20(4): 683-700.

[21] Carignan, V., Villard, M. A. (2002): Selecting indicator species to monitor ecological integrity: a review. - Environmental Monitoring and Assessment 78(1): 45-61.

[22] Casalini, A. I. (2017): Heterogeneity of the vegetation in the ecotone between the phytogeographic provinces of the mountains and Patagonia. Description and associated factors. - Revista Mexicana de Biodiversidad 86: 72-79.

[23] Casalini, A. I., Bouza, P. J., Bisigato, A. J. (2019): Geomorphology, soil and vegetation patterns in an arid ecotone. - Catena 174: 353-361.

[24] Chang, C.-T., Wang, H.-C., Huang, C.-Y. (2018): Assessment of modis-derived indices (2001-2013) to drought across Taiwan's forests. - International Journal of Biometeorology 62: 809-822.

[25] Chawla, A., Rajkumar, S., Singh, K. N., Lal, B., Singh, R. D., Thukral, A. K. (2008): Plant species diversity along an altitudinal gradient of Bhabha Valley in western Himalaya. - Journal of Mountain Science 5(2): 157-177.

[26] Clements, F. E. (1905): Research Methods in Ecology. - University Publishing Company, Lincoln, NE.

[27] Cochrane, M. A. (2003): Fire science for rainforests. - Nature 421: 913.

[28] Curtis, J. T., Mcintosh, R. P. (1950): The interrelations of certain analytic and synthetic phytosociological characters. - Ecology 31(3): 434-455.

[29] D'Amato, A. W., Fraver, S., Palik, B. J., Bradford, J. B., Patty, L. (2011): Singular and interactive effects of blowdown, salvage logging, and wildfire in sub-boreal pine systems. - Forest Ecology and Management 262(11): 2070-2078.

[30] Dalirsefat, S. B., da Silva Meyer, A., Mirhoseini, S. Z. (2009): Comparison of similarity coefficients used for cluster analysis with amplified fragment length polymorphism markers in the silkworm, Bombyx mori. - Journal of Insect Science 9(1).

[31] Day, P. R. (1965): Particle Fractionation and Particle-Size Analysis. - American Society of Agronomy, Soil Science Society of America, Madison, WI.

[32] Dolezal, J., Dvorsky, M., Kopecky, M., Liancourt, P., Hiiesalu, I., Macek, M., Altman, J., Chlumska, Z., Rehakova, K., Capkova, K. (2016): Vegetation dynamics at the upper elevational limit of vascular plants in Himalaya. - Scientific Reports 6: 24881.

[33] Dufrêne, M., Legendre, P. (1997): Species assemblages and indicator species: the need for a flexible asymmetrical approach. - Ecological Monographs 67(3): 345-366. 
[34] El-Keblawy, A., Abdelfattah, M. A., Khedr, A. H. A. (2015): Relationships between landforms, soil characteristics and dominant xerophytes in the hyper-arid northern United Arab Emirates. - Journal of Arid Environments 117: 28-36.

[35] Ewald, J. (2003): A critique for phytosociology. - Journal of Vegetation Science 14(2): 291-296.

[36] Francis, A. P., Currie, D. J. (1998): Global patterns of tree species richness in moist forests: another look. - Oikos 18(3): 598-602.

[37] Gauch, H. G. (2010): Multivariate analysis in community ecology. - Journal of the American Statistical Association 78(383): 735.

[38] Gauch, H. G., Gauch Jr, H. G. (1982): Multivariate Analysis in Community Ecology (No. 1). - Cambridge University Press, Cambridge, UK.

[39] Gebrekirstos, A., Teketay, D., Mitlöhner, R. (2014): Responses of Dobera glabra and eight co-occurring species to drought and salinity stress at a savanna-scrub ecotone: implications in the face of climate change. - Open Journal of Forestry 4: 327-337.

[40] Gonçalves, E. T., Souza, A. F. (2014): Floristic variation in ecotonal areas: patterns, determinants and biogeographic origins of subtropical forests in South America. - Austral Ecology 39: 122-134.

[41] Grellier, S., Florsch, N., Janeau, J. L., Podwojewski, P., Camerlynck, C., Barot, S., Ward, D., Lorentz, S. (2014): Soil clay influences Acacia encroachment in a South African grassland. - Ecohydrology 7(6): 1474-1484.

[42] Hansen, A. J., Risser, P. G., di Castri, F. (1992): Epilogue: Biodiversity and Ecological Flows across Ecotones. - In: Hansen, A. J., DiCastri, F. (eds.) Landscape Boundaries. Springer, New York, pp. 423-438.

[43] Haq, F., Ahmad, H., Iqbal, Z. (2015a): Vegetation composition and ecological gradients of subtropical-moist temperate ecotonal forests of Nandiar Khuwar catchment, Pakistan. - Bangladesh Journal of Botany 44(2): 267-276.

[44] Haq, F., Ahmad, H., Iqbal, Z. (2015b): Vegetation description and phytoclimatic gradients of subtropical forests of Nandiar Khuwar catchment District Battagram. Pakistan Journal of Botany 47(4): 1399-1405.

[45] Haq, F., Ahmad, H., Iqbal, Z., Alam, M., Aksoy, A. (2017): Multivariate approach to the classification and ordination of the forest ecosystem of Nandiar valley western Himalayas. - Ecological Indicators 80: 32-241.

[46] Huang, L., He, B., Chen, A., Wang, H., Liu, J., Lü, A., Chen, Z. (2016): Drought dominates the interannual variability in global terrestrial net primary production by controlling semi-arid ecosystems. - Scientific Reports 6: 24639.

[47] Ilyas, M., Shinwari, Z. K., Qureshi, R. (2012): Vegetation composition and threats to the montane temperate forest ecosystem of Qalagai hills, Swat, Khyber Pakhtunkhwa, Pakistan. - Pakistan Journal of Botany 44: 113-122

[48] Jobbágy, E. G., Jackson, R. B. (2001): The distribution of soil nutrients with depth: global patterns and the imprint of plants. - Biogeochemistry 53: 51-77.

[49] Johnstone, J. F., Chapin, F. S. (2003): Non-equilibrium succession dynamics indicate continued northern migration of lodgepole pine. - Global Change Biology 9(10): 14011409.

[50] Judi, D., Rakowski, C., Waichler, S., Feng, Y., Wigmosta, M. (2018): Integrated modeling approach for the development of climate-informed, actionable information. Water 10(6): 775.

[51] Kent, M. (2011): Vegetation Description and Data Analysis: A Practical Approach. John Wiley \& Sons, Chichester.

[52] Khan, S. M. (2012): Plant communities and vegetation ecosystem services in the Naran Valley, Western Himalaya. - Doctoral Dissertation, University of Leicester.

[53] Khan, S. M., Ahmad, H. (2015): Species Diversity and Use Patterns of the Alpine Flora with Special Reference to Climate Change in the Naran, Pakistan. - In: Öztürk, M. et al. 
(eds.) Climate Change Impacts on High-Altitude Ecosystems. Springer, Cham, pp. 155175.

[54] Khan, S. M., Page, S., Ahmad, H., Shaheen, H., Harper, D. M. (2012): Vegetation dynamics in the Western Himalayas, diversity indices and climate change. - Science Technology and Development 31(3): 232-243.

[55] Khan, S. M., Page, S., Ahmad, H., Ullah, Z., Shaheen, H., Ahmad, M., Harper, D. M. (2013): Phyto-climatic gradient of vegetation and habitat specificity in the high elevation Western Himalayas. - Pakistan Journal of Botany 45: 223-230.

[56] Khan, W., Khan, S. M., Ahmad, H. (2015): Altitudinal variation in plant species richness and diversity at Thandiani sub forests division, Abbottabad, Pakistan. - Journal of Biodiversity and Environmental Sciences 7: 46-53.

[57] Khan, W., Khan, S. M., Ahmad, H., Ahmad, Z., Page, S. (2016): Vegetation mapping and multivariate approach to indicator species of a forest ecosystem: A case study from the Thandiani sub Forests Division (TsFD) in the Western Himalayas. - Ecological Indicators 71: 336-351.

[58] Kupfer, J. A., Cairns, D. M. (1996): The suitability of montane ecotones as indicators of global climatic change. - Progress in Physical Geography 20(3): 253-272.

[59] Kusnierz, P. C., Holbrook, C. M., Feldman, D. L. (2015): An evaluation of a bed instability index as an indicator of habitat quality in mountain streams of the northwestern united states. - Environmental Monitoring and Assessment 187: 511-530.

[60] Laurance, W. F., Oliveira, A. A., Laurance, S. G., Condit, R., Nascimento, H. E., Sanchez-Thorin, A. C., Lovejoy, T. E., Andrade, A., D'angelo, S., Ribeiro, J. E., Dick, C. W. (2004): Pervasive alteration of tree communities in undisturbed Amazonian forests. Nature 428(6979): 171-174.

[61] Lloyd, K. M., Mcqueen, A. A., lee, B. J., Wilson, R. C., Walker, S., Wilson, J. B. (2000): Evidence on ecotone concepts from switch, environmental and anthropogenic ecotones. Journal of Vegetation Science 11(6): 903-910.

[62] Lyu, L., Suvanto, S., Nöjd, P., Henttonen, H. M., Mäkinen, H., Zhang, Q.-B. (2017): Tree growth and its climate signal along latitudinal and altitudinal gradients: comparison of tree rings between Finland and the Tibetan Plateau. - Biogeosciences 14: 3083-3095.

[63] Malik, R. N., Husain, S. Z. (2006): Classification and ordination of vegetation communities of the Lohibehr reserve forest and its surrounding areas, Rawalpindi, Pakistan. - Pakistan Journal of Botany 38(3): 543.

[64] Mashwani, Z. R., Arshad, M., Ahmad, M., Khan, M. A. (2011): Diversity and Distribution Pattern of Alpine Vegetation along Lake Saif-ul-Mulook, Western Himalaya, Pakistan. - In: International Conference on Environmental, Biomedical and Biotechnology IPCBEE (Vol. 16). IACSIT Press Singapore, pp. 155-163.

[65] McMahon, S. M., Harrison, S. P., Armbruster, W. S., Bartlein, P. J., Beale, C. M., Edwards, M. E., Kattge, J., Midgley, G., Morin, X., Prentice, I. C. (2011): Improving assessment and modelling of climate change impacts on global terrestrial biodiversity. Trends in Ecology \& Evolution 26(5): 249-259.

[66] Muthuramkumar, S., Ayyappan, N., Parthasarathy, N., Mudappa, D., Raman, T., Selwyn, M. A., Pragasan, 1. A. (2006): Plant community structure in tropical rain forest fragments of the western Ghats, India. - Biotropica 38: 143-160.

[67] Neilson, R. P. (1991): Climatic Constraints and Issues of Scale Controlling Regional Biomes. - In: Holland, M. M. et al. (eds.) Ecotones. Springer, Boston, MA, pp. 31-51.

[68] Nelson, D. W., Sommers, 1. E. (1996): Total Carbon, Organic Carbon, and Organic Matter. - In: Page, A. L. et al. (ed.) Methods of Soil Analysis. Part 3: Chemical Methods. SSSA, Madison, WI, pp. 961-1010.

[69] Niemi, G. J., McDonald, M. E. (2004): Application of ecological indicators. - Annual Review of Ecology, Evolution, and Systematics 35: 89-111.

[70] Pei, T., Qin, C. Z., Zhu, A. X., Yang, L., Luo, M., Li, B., Zhou, C. (2010): Mapping soil organic matter using the topographic wetness index: a comparative study based on 
different flow-direction algorithms and kriging methods. - Ecological Indicators 10(3): 610-619.

[71] Pharswan, K., Mehta, J. P., Subodh (2010): Floristic composition and biological spectrum of vegetation in alpine meadows of Kedarnath: Garhwal Himalaya. - Nature and Science 8(7): 109-115.

[72] Rahman, I. U., Hart, R., Afzal, A., Iqbal, Z., Ijaz, F., Ali, N., Abdallah, E. F., Khan, S. M., Alqarawi, A. A., Alsubeie M. S., Bussmann, R. W., 2019. A new ethnobiological similarity index (ESI) for the analysis of quantitative data. - Applied Ecology and Environmental Research, 17(2):2765-2777

[73] Rasul, G. (2010): The role of the Himalayan mountain systems in food security and agricultural sustainability in South Asia. - International Journal of Rural Management 6(1): 95-116.

[74] Rhoades, J. (1982): Soluble Salts. - In: Page, A. L. et al. (eds.) Methods of Soil Analysis. Part 2: Chemical and Microbiological Properties. SSSA, Madison, WI, pp. 167-178.

[75] Rhoades, J., Miyamoto, S. (1990): Testing Soils for Salinity and Sodicity. - In: Weterman, R. L. (ed.) Soil Testing and Plant Analysis. SSSA, Madison, WI, pp. 299-336.

[76] Rooney, T. P., Waller, D. M. (1998): Local and regional variation in hemlock seedling establishment in forests of the upper Great Lakes region, USA. - Forest Ecology and Management 111(2-3): 211-224.

[77] Rüger, N., Williams-Linera, G., Kissling, W. D., Huth, A. (2008): Long-term impacts of fuelwood extraction on a tropical montane cloud forest. - Ecosystems 11(6): 868-881.

[78] Saima, S., Dasti, A. A., Hussain, F., Wazir, S. M., Malik, S. A. (2009): Floristic compositions along an 18-km long transect in Ayubia National Park district Abbottabad, Pakistan. - Pakistan Journal of Botany 41(5):.2115-2127.

[79] Shaheen, H., Khan, S. M., Harper, D. M., Ullah, Z., Allem Qureshi, R. (2011): Species diversity, community structure, and distribution patterns in western Himalayan alpine pastures of Kashmir, Pakistan. - Mountain Research and Development 31: 153-159.

[80] Shaheen, H., Ullah, Z., Khan, S. M., Harper, D. M. (2012): Species composition and community structure of western Himalayan moist temperate forests in Kashmir. - Forest Ecology and Management 278: 138-145.

[81] Shaukat, S. S., Khan, M. A., Mett, M., Siddiqui, M. F. (2014): Structure, composition and diversity of the vegetation of Hub dam catchment area, Pakistan. - Pakistan Journal of Botany 46(1): 65-80.

[82] Shen, M., Piao, S., Jeong, S. J. et al. (2015): Evaporative cooling over the Tibetan Plateau induced by vegetation growth. - Proceedings of the National Academy of Sciences of the United States of America 112(30): 9299.

[83] Sher, H., Ahmad, A., Eleyemeni, M., Fazl-i-Hadi, S., Sher, H. (2010): Impact of nomadic grazing on medicinal plants diversity in Miandam, Swat-Pakistan (Preliminary results). International Journal of Biodiversity and Conservation 2(6): 146-154.

[84] Singh, H., Kumar, M., Sheikh, M. A. (2009): Distribution pattern of oak and pine along altitudinal gradients in Garhwal Himalaya. - Nature and Science 7: 81-85.

[85] Skagen, S. K., Augustine, D. J., Derner, J. D. (2018): Semi-arid grassland bird responses to patch-burn grazing and drought. - The Journal of Wildlife Management 82: 445-456.

[86] Soltanpour, P. N. (1985): Use of ammonium bicarbonate DTPA soil test to evaluate elemental availability and toxicity. - Communications in Soil Science and Plant Analysis 16(3): 323-338.

[87] Sorensen, T. (1948): A Method of Establishing Groups of Equal Amplitude in Plant Sociology Based on Similarity of Species Content and Its Application to Analyses of the Vegetation on Danish Commons. - I kommission hos E. Munksgaard, København, pp. 134.

[88] Sternberg, M., Golodets, C., Gutman, M., Perevolotsky, A., Kigel, J., Henkin, Z. (2017): No precipitation legacy effects on above-ground net primary production and species 
diversity in grazed Mediterranean grassland: a 21-year experiment. - Journal of Vegetation Science 28(2): 260-269.

[89] Tavili, A., Jafari, M. (2009): Interrelations between plants and environmental variables. International Journal of Environmental Research 3(2): 239-246.

[90] Ter Braak, C. J., Barendregt, L. G. (1986): Weighted averaging of species indicator values: its efficiency in environmental calibration. - Mathematical Biosciences 78(1):.5772.

[91] Ullah, Z., Ahmad, M., Sher, H., Shaheen, H., Khan, S. M. (2015): Phytogeographic analysis and diversity of the grasses and sedges (Poales) of northern Pakistan. - Pakistan Journal of Botany 47: 93-104.

[92] Vallés, S. M., Cambrollé, J., Gallego-Fernández, J. B. (2015): Effect of soil characteristics on plant distribution in coastal ecosystems of SW Iberian Peninsula sand spits. - Plant Ecology 216: 1551-1570.

[93] Walker, S., Wilson, J. B., Steel, J. B., Rapson, R., Smith, B., King, W. M., Cottam, Y. H. (2003): Properties of ecotones: evidence from five ecotones objectively determined from a coastal vegetation gradient. - Journal of Vegetation Science 14: 579-590.

[94] Wangda, P. (2003): Forest zonation along the complex altitudinal gradients in a dry valley of Punatsang-Chu, Bhutan. - Master's Thesis, The University of Tokyo, Japan.

[95] Willig, M. R., Kaufman, D. M., Stevens, R. D. (2003): Latitudinal gradients of biodiversity: pattern, process, scale, and synthesis. - Annual Review of Ecology, Evolution, and Systematics 34(1): 273-309.

[96] Zhou, C. W., Yang, R., Yu, L. F., Zhang, Y., Yan, L. B. (2018): Hydrological and ecological effects of climate change in Caohai watershed based on SWAT model. Applied Ecology and Environmental Research 17(1): 161-172.

\section{APPENDIX}

Table A1. Plant check of the ecotonal region, along with a detail of their families, habit and IVI\%

\begin{tabular}{|c|c|c|c|c|c|c|c|c|c|}
\hline S/No. & Botanical name & Family & Habit & IVI\% & S/No. & Botanical name & Family & Habit & IVI\% \\
\hline 1 & $\begin{array}{c}\text { Adiantum capillus } \\
\text { veneris }\end{array}$ & Pteridaceae & Herb & 0.34 & 99 & Morus nigra & Moraceae & Tree & 0.52 \\
\hline 2 & Adiantum venustum & Pteridaceae & Herb & 0.77 & 100 & Myrtus communis & Myrtaceae & Shrub & 2.38 \\
\hline 3 & Agrostis vinealis Schreb & Poaceae & Herb & 2.11 & 101 & Nasturtium officinale & Brassicaceae & Herb & 0.16 \\
\hline 4 & Ailanthus altissima & Simaroubaceae & Tree & 3.53 & 102 & Nepeta Spp & Lamiaceae & Herb & 0.05 \\
\hline 5 & Amaranthus retroflexus & Amaranthaceae & Herb & 0.08 & 103 & Nepeta erecta & Lamiaceae & Herb & 0.32 \\
\hline 6 & Amaranthus viridis & Amaranthaceae & Herb & 0.08 & 104 & Nepeta laevigata & Lamiaceae & Herb & 0.46 \\
\hline 7 & Androsace rotundifolia & Primulaceae & Herb & 0.27 & 105 & Oenothera rosea & Onagraceae & Herb & 1.16 \\
\hline 8 & Anisomeles indica & Lamiaceae & Herb & 0.21 & 106 & Olea ferruginea & Oleaceae & Tree & 7.60 \\
\hline 9 & Apluda mutica & Poaceae & Herb & 2.56 & 107 & Origanum vulgare & Lamiaceae & Herb & 0.46 \\
\hline 10 & Arisaema flavum & Araceae & Herb & 0.29 & 108 & Oxalis corniculata & Oxalidaceae & Herb & 2.71 \\
\hline 11 & Artemisia absinthium & Asteraceae & Herb & 0.11 & 109 & Parrotiopsis jacquemontiana & Hamamelidaceae & Tree & 1.13 \\
\hline 12 & Arthraxon prionodes & Poaceae & Herb & 0.10 & 110 & Paspalum paspalodes & Poaceae & Herb & 0.13 \\
\hline 13 & Avena fatua & Poaceae & Herb & 0.40 & 111 & Persicaria hydropiper & Polygonaceae & Herb & 0.04 \\
\hline 14 & Berberis lysium & Berberidaceae & Shrub & 7.99 & 112 & Persicaria maculosa & Polygonaceae & Herb & 0.82 \\
\hline 15 & Berberis parkeriana & Berberidaceae & Shrub & 7.39 & 113 & Phagnalon niveum & Asteraceae & Herb & 0.22 \\
\hline 16 & Bidens bipinnata & Asteraceae & Herb & 0.09 & 114 & Phlomis stewartii & Lamiaceae & Herb & 1.66 \\
\hline 17 & Bidens cernua & Asteraceae & Herb & 0.23 & 115 & Pinus brutia & Pinaceae & Tree & 1.37 \\
\hline 18 & Bidens tripartite & Asteraceae & Herb & 0.20 & 116 & Piptatherum laterale & Poaceae & Herb & 2.69 \\
\hline 19 & Bistorta amplexicaulis & Polygonaceae & Herb & 0.43 & 117 & Plantago lanceolata & Plantaginaceae & Herb & 2.12 \\
\hline 20 & Bothriochloa bladhii & Poaceae & Herb & 1.66 & 118 & Plantago major & Plantaginaceae & Herb & 0.15 \\
\hline 21 & Bromus japonicas & Poaceae & Herb & 0.38 & 119 & Platanus orientalis & Platanaceae & Tree & 1.30 \\
\hline
\end{tabular}




\begin{tabular}{|c|c|c|c|c|c|c|c|c|c|}
\hline 22 & Buddleja crispa & Buddlejaceae & Shrub & 0.16 & 120 & Plectranthus rugosus & Lamiaceae & Shrub & 14.81 \\
\hline 23 & Bupleurum falcatum & Apiaceae & Herb & 1.93 & 121 & Polygala abyssinica & Polygalaceae & Herb & 0.27 \\
\hline 24 & Bupleurum linearifolium & Apiaceae & Herb & 0.10 & 122 & Polygonum aviculare & Polygonaceae & Herb & 0.44 \\
\hline 25 & Calamintha umbrosa & Lamiaceae & Herb & 0.45 & 123 & Polygonum plebejum & Polygonaceae & Herb & 0.24 \\
\hline 26 & Calanthe tricarinata & Orchidaceae & Herb & 0.05 & 124 & Polypogon fugax & Poaceae & Herb & 0.08 \\
\hline 27 & Campanula pallida & Campanulaceae & Herb & 0.36 & 125 & Popolus nigra & Salicaceae & Tree & 6.08 \\
\hline 28 & Cannabis sativa & Cannabaceae & Herb & 1.38 & 126 & Populus alba & Salicaceae & Tree & 0.19 \\
\hline 29 & Cedrus deodara & Pinaceae & Tree & 6.37 & 127 & Potentilla anserina & Rosaceae & Herb & 0.55 \\
\hline 30 & Celtis caucasica & Ulmaceae & Tree & 3.63 & 128 & Potentilla supina & Rosaceae & Herb & 0.79 \\
\hline 31 & Centaurea calcitrapa & Asteraceae & Herb & 0.08 & 129 & Prunella vulgaris & Lamiaceae & Herb & 0.29 \\
\hline 32 & Centaurea iberica & Asteraceae & Herb & 0.20 & 130 & Prunus armeniaca & Rosaceae & Tree & 0.67 \\
\hline 33 & Chenopodium album & Chenopodiaceae & Herb & 0.11 & 131 & Prunus eburnea & Rosaceae & Tree & 2.51 \\
\hline 34 & Cichorium intybus & Asteraceae & Herb & 0.29 & 132 & Punica grantum & Lythraceae & Tree & 5.04 \\
\hline 35 & Cirsium arvense & Asteraceae & Herb & 3.91 & 133 & Pyrus pashia & Rosaceae & Tree & 0.10 \\
\hline 36 & Cirsium vulgare & Asteraceae & Herb & 0.24 & 134 & Quercus baloot & Fagaceae & Tree & 8.63 \\
\hline 37 & Clematis grata & Ranunculaceae & Herb & 0.41 & 135 & Quercus dilatata & Fagaceae & Tree & 17.11 \\
\hline 38 & Clematis graveolens & Ranunculaceae & Herb & 0.44 & 136 & Quercus semecarpifolia & Fagaceae & Tree & 0.80 \\
\hline 39 & Clematis orientalis & Ranunculaceae & Herb & 0.32 & 137 & Ranunculus arvensis & Ranunculaceae & Herb & 0.55 \\
\hline 40 & Clinopodium umbrosum & Lamiaceae & Herb & 0.58 & 138 & Ranunculus laetus & Ranunculaceae & Herb & 0.16 \\
\hline 41 & Convolvulus arvensis & Convolvulaceae & Herb & 0.67 & 139 & Ranunculus repens & Ranunculaceae & Herb & 0.60 \\
\hline 42 & Cotoneaster bacillaris & Rosaceae & Tree & 0.33 & 140 & Raphanus raphanistrum & Brassicaceae & Herb & 0.13 \\
\hline 43 & Cotoneaster nummularia & Rosaceae & Tree & 3.79 & 141 & Robinia pseudoacacia & Fagaceae & Tree & 11.01 \\
\hline 44 & Crataegus songarica & Rosaceae & Tree & 0.67 & 142 & Rorippa islandica & Brassicaceae & Herb & 0.03 \\
\hline 45 & Cymbopogon jwarancusa & Poaceae & Herb & 0.42 & 143 & Rosa chinensis & Rosaceae & Shrub & 3.70 \\
\hline 46 & Cynodon dactylon & Poaceae & Herb & 7.73 & 144 & Rosa moschata & Rosaceae & Shrub & 1.17 \\
\hline 47 & $\begin{array}{l}\text { Cynoglossum } \\
\text { lanceolatum }\end{array}$ & Boraginaceae & Herb & 0.09 & 145 & Rosa webbiana & Rosaceae & Shrub & 0.30 \\
\hline 48 & Cyperus rotundus & Cyperaceae & Herb & 0.22 & 146 & Rosa X alba & Rosaceae & Shrub & 0.18 \\
\hline 49 & Daphne mucronata & Thymelaeaceae & Shrub & 8.58 & 147 & Rubia cordifolia & Rubiaceae & Herb & 0.98 \\
\hline 50 & Datura stramonium & Solanaceae & Herb & 0.05 & 148 & Rubus fruticosus & Rosaceae & Shrub & 4.31 \\
\hline 51 & Debregeasia salicifolia & Urticaceae & Shrub & 0.16 & 149 & Rumex acetosa & Polygonaceae & Herb & 0.05 \\
\hline 52 & Dichanthium annulatum & Poaceae & Herb & 0.45 & 150 & Rumex dentatus & Polygonaceae & Herb & 0.67 \\
\hline 53 & Digitaria nodosa & Poaceae & Herb & 0.07 & 151 & Rumex nepalensis & Polygonaceae & Herb & 0.06 \\
\hline 54 & Diospyros lotus & Ebenaceae & Tree & 2.14 & 152 & Saccharum griffithii & Poaceae & Herb & 0.07 \\
\hline 55 & Duchesnea indica & Rosaceae & Herb & 0.78 & 153 & Saccharum spontaneum & Poaceae & Herb & 1.17 \\
\hline 56 & Elaegnes aungustifola & Elaeagnaceae & Tree & 3.18 & 154 & Salix alba & Salicaceae & Tree & 3.48 \\
\hline 57 & Elymus nutans & Poaceae & Herb & 0.09 & 155 & Salix babylonica & Salicaceae & Tree & 0.87 \\
\hline 58 & Ephedra procera & Ephedraceae & Shrub & 3.40 & 156 & Sambucus nigra & Sambucaceae & Shrub & 7.90 \\
\hline 59 & Epilobium hirsutum & Onagraceae & Herb & 0.04 & 157 & Sanguisorba minor & Rosaceae & Herb & 0.79 \\
\hline 60 & Equisetum debile & Equisetaceae & Herb & 0.18 & 158 & Sauromatum venosum & Araceae & Herb & 0.16 \\
\hline 61 & Eragrostis pilosa & Poaceae & Herb & 0.08 & 159 & Saussuria heteromalla & Asteraceae & Herb & 2.41 \\
\hline 62 & Eragrostis tenella & Poaceae & Herb & 0.05 & 160 & Scrophularia striata & Scrophulariaceae & Herb & 0.44 \\
\hline 63 & Erigeron bonariensis & Asteraceae & Herb & 0.21 & 161 & Scutellaria linearis & Lamiaceae & Herb & 0.77 \\
\hline 64 & Erigeron canadensis & Asteraceae & Herb & 0.98 & 162 & Seriphidium kurramense & Asteraceae & Herb & 0.49 \\
\hline 65 & Eryngium billardieri & Apiaceae & Herb & 0.14 & 163 & Setaria pumila & Poaceae & Herb & 3.26 \\
\hline 66 & Eryngium coeruleum & Apiaceae & Herb & 0.11 & 164 & Solanum americanum & Solanaceae & Herb & 0.12 \\
\hline 67 & Euphorbia helioscopia & Euphorbiaceae & Herb & 0.17 & 165 & Solanum nigrum & Solanaceae & Herb & 0.06 \\
\hline 68 & Festuca gigantea & Poaceae & Herb & 0.38 & 166 & $\begin{array}{c}\text { Solanum nigrum var. } \\
\text { villosum }\end{array}$ & Solanaceae & Herb & 0.05 \\
\hline 69 & Ficus palmata & Moraceae & Tree & 0.47 & 167 & Sonchus asper & Asteraceae & Herb & 0.14 \\
\hline 70 & Foeniculum vulgare & Apiaceae & Herb & 0.09 & 168 & Sonchus oleraceus & Asteraceae & Herb & 0.29 \\
\hline 71 & Fragaria nubicola & Rosaceae & Herb & 0.07 & 169 & Sophora mollis & Papilionaceae & Shrub & 12.17 \\
\hline 72 & Galinsoga parviflora & Asteraceae & Herb & 0.29 & 170 & Stellaria media & Caryophyllaceae & Herb & 0.22 \\
\hline 73 & Hedera nepalensis & Araliaceae & Shrub & 0.39 & 171 & Stipa sibirica & Poaceae & Herb & 3.72 \\
\hline 74 & Impatiens edgeworthii & Balsaminaceae & Herb & 1.50 & 172 & Strobilanthes urticifolia & Acanthaceae & Herb & 0.29 \\
\hline 75 & Impatiens lemannii & Balsaminaceae & Herb & 0.20 & 173 & Swertia cordata & Gentianaceae & Herb & 0.92 \\
\hline
\end{tabular}


Hussain et al.: Assessment of plant communities and identification of indicator species of an ecotonal forest zone at Durand Line, District Kurram, Pakistan

$-6396-$

\begin{tabular}{|c|c|c|c|c|c|c|c|c|c|}
\hline 76 & Indigofera heterantha & Papilionaceae & Shrub & 19.04 & 174 & Tagetes minuta & Asteraceae & Herb & 0.77 \\
\hline 77 & Ipomoea purpurea & Convolvulaceae & Herb & 1.03 & 175 & Taraxacum officinale & Asteraceae & Herb & 0.70 \\
\hline 78 & Jasminum auriculatum & Oleaceae & Shrub & 0.24 & 176 & Themeda anathera & Poaceae & Herb & 0.15 \\
\hline 79 & Jasminum officinale & Oleaceae & Shrub & 0.62 & 177 & Thuja orientalis & Cupressaceae & Shrub & 0.59 \\
\hline 80 & Juglans regia & Juglandaceae & Tree & 2.73 & 178 & Thymus linearis & Lamiaceae & Herb & 5.03 \\
\hline 81 & Juniperus excelsa & Cupressaceae & Tree & 0.97 & 179 & Torilis leptophylla & Apiaceae & Herb & 1.07 \\
\hline 82 & $\begin{array}{c}\text { Leontopodium } \\
\text { brachyactis }\end{array}$ & Asteraceae & Herb & 0.08 & 180 & Tragopogon gracilis & Asteraceae & Herb & 0.03 \\
\hline 83 & Lepidium pinnatifidum & Brassicaceae & Herb & 0.38 & 181 & Trifolium alexandrianum & Papilionaceae & Herb & 0.19 \\
\hline 84 & Lespedeza juncea & Papilionaceae & Herb & 1.44 & 182 & Trifolium repens & Papilionaceae & Herb & 0.76 \\
\hline 85 & Liriope graminifolia & Haemodoraceae & Herb & 0.10 & 183 & Urtica dioica & Urticaceae & Herb & 0.07 \\
\hline 86 & Lotus corniculatus & Papilionaceae & Herb & 0.96 & 184 & Verbena officinalis & Verbenaceae & Herb & 0.15 \\
\hline 87 & Malus domestica & Rosaceae & Tree & 0.21 & 185 & Verbena Linn., & Verbenaceae & Herb & 0.05 \\
\hline 88 & Malva neglecta & Malvaceae & Herb & 0.36 & 186 & $\begin{array}{c}\text { Vincetoxicum } \\
\text { cardiostephanum }\end{array}$ & Apocynaceae & Herb & 0.78 \\
\hline 89 & Marrubium vulgare & Lamiaceae & Herb & 0.05 & 187 & Viola canescens & Violaceae & Herb & 0.70 \\
\hline 90 & Matricaria recutita & Asteraceae & Herb & 0.54 & 188 & Viola odorata & Violaceae & Herb & 2.44 \\
\hline 91 & Medicago lupulina & Papilionaceae & Herb & 0.50 & 189 & Viola pilosa & Violaceae & Herb & 0.71 \\
\hline 92 & Medicago sativa & Papilionaceae & Herb & 6.16 & 190 & Viola reichenbachiana & Violaceae & Herb & 0.14 \\
\hline 93 & Mentha arvensis & Lamiaceae & Herb & 0.13 & 191 & Viola spp. & Violaceae & Herb & 0.09 \\
\hline 94 & Mentha longifolia & Lamiaceae & Herb & 1.52 & 192 & Wikstroemia canescens & Thymelaeaceae & Shrub & 4.51 \\
\hline 95 & Mentha royleana & Lamiaceae & Herb & 0.54 & 193 & Wulfeniopsis amherstiana & Plantaginaceae & Herb & 0.13 \\
\hline 96 & Micromeria biflora & Lamiaceae & Herb & 0.09 & 194 & Xanthium spinosum & Asteraceae & Herb & 1.91 \\
\hline 97 & Monotheca buxifolia & Sapotaceae & Tree & 2.56 & 195 & Xanthium strumarium & Asteraceae & Herb & 0.40 \\
\hline 98 & Morus alba & Moraceae & Tree & 1.03 & & & & & \\
\hline
\end{tabular}

